\title{
Uneasy Lies the Head that Wears the Crown: Historical Vignette on Chronic Traumatic Encephalopathy
}

\author{
Prasad Krishnan ${ }^{1, \odot ~ C h a n d r a m o u l i ~ B h a t t a c h a r y a ² ~}$ \\ ${ }^{1}$ Department of Neurosurgery, National Neurosciences Centre, \\ Kolkata, West Bengal, India \\ ${ }^{2}$ Department of Internal Medicine, Peerless Hospital, Kolkata, West \\ Bengal, India \\ ${ }^{3}$ Department of Neuroaneshesiology, National Neurosciences \\ Centre, Kolkata, West Bengal, India
}

Indian J Neurotrauma 2022;19:57-58.

Progressive neurological deterioration in boxers who suffer repeated traumatic brain injury (TBI) was termed chronic traumatic encephalopathy (CTE) by Macdonald Critchley. ${ }^{1}$ Behavioral changes including emotional lability, slowness of speech and thought, memory deterioration, mood swings, irritability, depression, paranoia, and uninhibited violent behavior are the features of CTE. ${ }^{1}$ The victims also have a combination of pyramidal, extrapyramidal, and cerebellar signs. ${ }^{1}$ CTE is now increasingly documented in athletes involved in contact sports. ${ }^{2}$ It is a neurodegenerative disorder akin to Alzheimer's disease, with perivascular accumulation of phosphorylated tau proteins in neurons and astrocytes at the depths of the cortical sulci. ${ }^{2}$

Clinically, CTE is divided into four stages, based on the increasing disability of the patients (-Table 1). CTE has gained recognition only recently, as, historically, there is sparse documentation of repetitive head injury, leading to behavioral alterations. We present two documented cases of startling personality changes and psychological decline in kings who suffered from repeated TBI.

\section{Rulers with CTE}

\section{Alexander the Great (356-323 BC)}

Alexander the Great, king of Macedon, conquered a large empire and is considered one of history's greatest military commanders. ${ }^{3}$ In his youth, he was an intelligent, well-educated, charismatic man with musical abilities as well. ${ }^{3}$

published online

July 29, 2021
DOI https://doi.org/

10.1055/s-0041-1732794

ISSN 0973-0508
Nabanita Ghosh ${ }^{3}$

Address for correspondence Prasad Krishnan, MS, MCh, Department of Neurosurgery, National Neurosciences Centre, 2nd Floor, Peerless Hospital Campus, 360, Panchasayar, Garia 700094, Kolkata, West Bengal, India (e-mail: prasad.krishnan@ rediffmail.com).

He suffered numerous injuries during his campaigns because of his short height, which brought him in close contact with his opponents, and on account of his tendency of leading from the front in battle. ${ }^{4}$ In the Balkan campaign, a stone hit his head, while in the Battle of the Granicus, a head blow shattered his helmet. ${ }^{4} \mathrm{~A}$ bird dropped a stone on his head prior to the siege of Gaza, and while besieging Cyropolis, a head injury resulted in a partial transient loss of vision. ${ }^{4}$ In his Indian campaign, too, he lost consciousness and had projectiles showered on his head from above. ${ }^{4}$

Following these injuries, his ability to speak, walk, ride, and fight were impaired in the Scythian campaign. ${ }^{4}$ Over time, he turned increasingly ill-tempered and violent, burning the palace of Persepolis and killing loyal commanders (Kletios) in fits of rage. ${ }^{4} \mathrm{He}$ also became paranoid and suffered from delusions of persecution, killing his old companions (Philotas and Parmenion) for trivial reasons. ${ }^{4} \mathrm{He}$ had bouts of depression and even attempted suicide. ${ }^{4}$ While he was prone to inconsolable grief (after Hephaestion's death), he became increasingly reckless in his later campaigns, with impairment of judgement which resulted in the death of 75\% of his men as he made his army undertake a foolhardy return trek through the desert to Alexandria. ${ }^{4}$

\section{Henry VII (1491-1547 AD)}

Henry VIII, King of England (1509-1547) is one of the most important rulers in English history. ${ }^{5}$ In his reign, the Church of England broke away from the Roman Catholic Church and the papal authority, the Royal Navy was strengthened, and the Guild of Barbers and Surgeons came into existence. (c) 2021. Neurotrauma Society of India.

This is an open access article published by Thieme under the terms of the Creative Commons Attribution-NonDerivative-NonCommercial-License, permitting copying and reproduction so long as the original work is given appropriate credit. Contents may not be used for commercial purposes, or adapted, remixed, transformed or built upon. (https://creativecommons.org/licenses/by-nc-nd/4.0/).

Thieme Medical and Scientific Publishers Pvt. Ltd. A-12, 2nd Floor, Sector 2, Noida-201301 UP, India 
Table 1 Stages of chronic traumatic encephalopathy (adapted from Turk and Budson²)

\begin{tabular}{|l|l|}
\hline Stage 1 & Headaches with loss of attention and concentration \\
\hline Stage 2 & $\begin{array}{l}\text { Stage } 1 \text { features with explosiveness, short-term } \\
\text { memory loss, mood swings and depression }\end{array}$ \\
\hline Stage 3 & $\begin{array}{l}\text { Worsening of stage } 2 \text { features with cognitive } \\
\text { impairment, executive dysfunction and visuospatial } \\
\text { abnormalities }\end{array}$ \\
\hline Stage 4 & $\begin{array}{l}\text { Worsening of stage } 3 \text { symptoms with dementia, par- } \\
\text { anoia, aggression, impulsivity and motor problems } \\
\text { (Parkinsonism, gait and speech abnormalities) }\end{array}$ \\
\hline
\end{tabular}

When young, he served as an intelligent and understanding monarch, who was a loving husband and considerate and generous to others. ${ }^{5}$ Receiving a modern humanist education, he was a polyglot, bibliophile, author, and musician, all rolled into one. ${ }^{5}$ Fond of jousting and fighting with swords, he used to indulge in this pastime regularly during which he received several blows to the head. ${ }^{6}$ A well-documented head injury occurred on March 10,1524, and in 1525, attempting to vault over a hedge, he fell and concussed in a ditch of water. ${ }^{7}$ Over time, that is, 1531 onward, he had worsening headaches and developed insomnia and restlessness. ${ }^{6}$ On January 24 , 1536 , he suffered another jousting accident with loss of consciousness for 2 hours. ${ }^{6}$ Over time, he grew heavier, became paranoid, and suffered from memory loss with outbursts of anger, depression, and sociopathy. ${ }^{7}$ Once cheery and good natured, he had his wives and counsellors executed., ${ }^{5,7}$ it is now believed that his decline in mood followed his head injury and that the gain in weight was not due to his "marvelously excessive" appetite, but due to neuroendocrine deficiency following repeated TBI.,

\section{Conclusion}

Both these kings fulfilled the criteria required for the injuries to cause CTE syndrome, that is, mild TBI or concussion (minimum documented four episodes) or moderate/severe TBI (two episodes with loss of consciousness of at least 30 minutes) or repetitive subconcussive trauma. ${ }^{2}$ Due to lack of awareness of this condition, no avoidance measures were taken by either of these rulers as their higher mental faculties, personalities, and behavior slowly worsened, causing suffering to themselves and their contemporaries.

\section{Conflict of Interest}

None declared.

\section{References}

1 Critchley M. Medical aspects of boxing, particularly from a neurological standpoint. BMJ 1957;1(5015):357-362

2 Turk KW, Budson AE. Chronic traumatic encephalopathy. Continuum (Minneap Minn 2019;25(1):187-207

3 Wikipedia contributors. Alexander the Great. Accessed May 3, 2021 at: https://en.wikipedia.org/w/index.php?title= Alexander_the_Great\&oldid=1021141213.

4 Morris AF. Alexander the Great: head to head with CTE (Chronic Traumatic Encephalopathy) Athens J Hist 2017;3:225-234

5 Wikipedia contributors. Henry VIII. Accessed May 3, 2021 at: https://en.wikipedia.org/w/index.php?title=Henry_VIII\&oldid= 1020377875

6 Chamberlin FC, The Private Character of Henry the Eighth. New York: Washburn; 1931

7 Ikram MQ Sajjad FH, Salardini A. The head that wears the crown: Henry VIII and traumatic brain injury. J Clin Neurosci 2016;28:16-19 